\title{
Can seed dispersal by human activity play a useful role for the conservation of European grasslands?
}

1. Alistair G. Auffret

Article first published online: 4 MAR 2011

DOI: 10.1111/j.1654-109X.2011.01124.x

(C) 2011 International Association for Vegetation Science

Issue

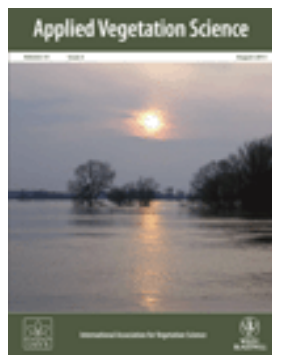

\section{Applied Vegetation Science}

Volume 14, Issue 3, pages 291-303, August 2011

Submitted version - pre-referreed. 


\section{Applied Vegetation Seienes}

\section{Human mediated seed dispersal for conservation in the European rural landscape}

\begin{tabular}{|r|l|}
\hline Journal: & Applied Vegetation Science \\
\hline Manuscript ID: & AVS-A-00351 \\
\hline Manuscript Category: & Ordinary article \\
\hline Date Submitted by the \\
Author: & 04-Aug-2010 \\
\hline Complete List of Authors: & $\begin{array}{l}\text { Auffret, Alistair; Stockholm University, Department of Physical } \\
\text { Geography and Quaternary Geology }\end{array}$ \\
\hline Keywords: & $\begin{array}{l}\text { Anthropocory, Conservation, Grassland, Long-distance dispersal, } \\
\text { Restoration, Zoochory }\end{array}$ \\
\hline
\end{tabular}


5 Address: Department of Physical Geography and Quaternary Geology, Stockholm University, 10691,

6 Stockholm, Sweden.

7 Telephone: +4686747568

$8 \quad$ Facsimile (department): +468164818

9 Email: alistair.auffret@natgeo.su.se

10

11

12

13

14

15

16 


\section{Abstract}

19 Objective: To summarise the recent research into human-mediated dispersal (HMD) in the European rural 20 landscape.

21 Methods: A thorough literature search was undertaken to explore the potential for HMD vectors, both standard and non-standard, how they have changed through time, and their implications for conservation.

23 Results: Grazing animals provide an important source of propagules, but other, non-standard means of dispersal such as via clothing and motor vehicles can also transport seeds of many species. Dispersal is an important consideration for the conservation and restoration of species rich grasslands, and a lot can be gained by drawing inspiration from the past agricultural practices.

Recommendations: There should be a greater movement of grazing animals throughout the landscape, and the spreading of hay or dung from species-rich communities to target sites should be considered. There should be further investigation of the potential dispersal via human activities, and future research should be conducted at the landscape scale.

Keywords: Anthropocory, Conservation, Grassland, Long-distance dispersal, Restoration, Zoochory 


\section{Introduction}

Throughout history, and at an accelerating rate recently, humans have influenced the dispersal of plant species through their actions (Hodkinson et al. 1997). Human-mediated dispersal (HMD) has been recently defined as dispersal directly by humans, as well as that by human associated vectors, such as transport and livestock (Wichmann et al. 2009). Twelve years ago, Poschlod and Bonn (1998) described the changing dispersal processes in the European rural landscape, and much of the empirical knowledge into how past and present land practices aid or hinder the transport of species in the landscape has been gained since then.

European semi-natural grasslands are inherently influenced by man, maintained through the long term grazing and mowing of areas within various agricultural systems, which started from around the Neolithic period (see Poschlod et al. 2002). This continuous management over millennia has led to these habitats today being among the most species rich in Europe, with over 40 plant species found per square metre in Swedish grasslands (Eriksson et al. 1997, Eriksson et al. 2006), 63 in an Estonian wooded meadow (Kull et al. 1991), and 67 in a Czech meadow (Klimeš et al. 2001). Cessation of management (abandonment), or conversion to arable land during the past two centuries has been widespread across Europe, resulting in severely reduced area and increased fragmentation (Adriaens et al. 2006, Bender et al. 2005a, Cousins et al. 2002, Fuller 1987, Johansson et al. 2008, Luoto et al. 2003, Pärtel et al. 1999). In addition to the reduction in habitat area, large scale fragmentation is often associated with biological impoverishment of remaining fragments (Harrison et al. 1999), and the increasing amount of matrix in the agricultural landscape has created a barrier for the dispersal of grassland plant species, which is essential for the maintenance of viable metapopulations (Hanski 1999).

Site history is embedded in the structure and function of all ecosystems (Foster et al. 2003), and exercises using historical sources reveal that community composition in remaining and abandoned semi-natural habitats often 
61 appears to be related to historical landscape configuration (but see Adriaens et al. 2006, Chýlová et al. 2008,

62 Dahlström et al. 2006, Gustavsson et al. 2007, Helm et al. 2006, Lindborg et al. 2004, Maurer et al. 2003, Pärtel

63

64 et al. 2007). This means that so-called 'extinction debts' (Tilman et al. 1994), where there exists a time delay between habitat destruction and species disappearance are fairly common in semi-natural landscapes. As well as the persistence of species in remaining grasslands, remnant populations can also be found in surrounding habitats such mid-field islets, road verges, field boundaries and abandoned farmland (Cousins 2006, Cousins et al. 2001, Cousins et al. 2008, Dahlström et al. published online, Hovd et al. 2005, Simmering et al. 2006, Smart et al. 2002).

The existence of extinction debts and remnant populations is promising with regards to restoration potential, but seed-sowing experiments regularly find that grassland plant species dispersal or seed limited (Ehrlén et al. 2006, Franzén et al. 2003, Gross et al. 2005, Münzbergová 2004, Primack et al. 1992, Stein et al. 2008). The degree of dispersal limitation increases with isolation of the focal site (Ozinga et al. 2005), and therefore plant species may require long-distance dispersal (LDD) (Nathan 2006). LDD is thought to be most prevalent in open terrestrial landscapes, mediated by large animals (Nathan et al. 2008), as well as by non-standard dispersal vectors such as via human activity (Higgins et al. 2003). The potential therefore exists for successful dispersal of grassland plants in the fragmented agricultural landscape, largely by human associated vectors.

Research into dispersal mechanisms in grassland communities is therefore important, and here I will review HMD vectors in semi-natural landscapes throughout history, and discuss their implications for conservation. In Table 1 I have summarised the findings of the 22 research articles found via searching the ISI Web of Science ${ }^{\circledR}$, plus studies referenced within, of seeds dispersed via human-mediated vectors under natural conditions (i.e. samples taken from vector without any seed addition) in Europe. 


\section{HMD vectors in the rural landscape}

87

88

\subsection{Grazing animals}

89

2.1.1.

91 Before the widespread introduction of agriculture, a woodland-grassland mosaic was maintained through the 92 presence of large wild herbivores (Vera 2000). Species such as fallow deer (Dama dama), European bison 93 (Bison bonasus), Red deer (Cervus elaphus), roe deer (Capreolus capreolus) and wild boar (Sus scrofa) have 94 been found to be effective seed dispersers, both epi (outside)- and endozoochorously (inside the animal) (Jaroszewicz et al. 2009, Kiviniemi 1996, Schmidt et al. 2004, von Oheimb et al. 2005).

96

\subsubsection{Epizoochory}

In semi-natural grasslands, grazing livestock have taken over this role, and seeds adapted to epizoochorous dispersal can be very effective at travelling in the fur of grazing animals. Fischer et al. (1996) found that $100 \%$ of species with hooked diaspores, $86 \%$ of bristly and $85 \%$ of coarse surfaced diaspores present in the study area were found in the fur an experimental sheep. Even $52 \%$ of species with smooth seeds were represented in the fleece. In a Dutch experiment, 'dummy' sheep and cattle were found to carry the seeds of 13 out of 15 fruiting species in an experimental area of a nature reserve (Mouissie et al. 2005a). The potential for so-called nonadapted seeds to disperse in this way has been reported elsewhere, with around a quarter of species represented in germinable seeds found in the coats of donkeys, cattle and horses not specialised to any particular dispersal 
105

106

107

108

109

110

111

112

113

114

115

116

117

118

119

120

121

122

123

124

125

126

127

vector (Couvreur et al. 2004a), and unappendaged seeds were found to have a higher attachment potential (\% remaining after $1 \mathrm{hr}$ mechanical shake) than both elongated and flat seeds in cattle fur, and flat seeds in sheep fleeces (Römermann et al. 2005). An experiment looking at small-seeded species from Spanish grasslands (de Pablos et al. 2007) showed that unappendaged seeds had an attachment potential of $79.5 \%$. It is thought likely that nearly all plant species have the potential to disperse epizoochorously (Couvreur et al. 2004b).

Attempts to quantify attachment times and distances for epizoochorous seed dispersal reveal the potential for seed transportation. Seeds of 12 species with varying morphologies in a nature reserve in Belgium found that at least $20 \%$ of seeds of all species applied remained on the fur of Haflinger horse after $3 \mathrm{hr}$ and Galloway cattle after 20 hours in natural conditions (Couvreur et al. 2005b). Studies in Sweden found maximum retention time of 35-195 minutes of 10-20 seeds of grassland species in the fur of domestic cattle, however the lethargic behaviour of the animals ( 4 metres movement per minute) resulted in projected distances of only a few hundred metres (Kiviniemi 1996, Kiviniemi et al. 1999). In reality however, the number of seeds transported on grazing animals can be very high indeed (see Table 1).

\subsubsection{Endozoochory}

Endozoochorous seed dispersal by grazers is another effective means of transporting species in semi-natural grasslands, with numerous seeds of many species found in their dung (Table 1). There is great also potential for long distance dispersal by this vector, not least because of the guaranteed transportation time associated with it, with mean retention of germinable seeds of 50-70 hours for cattle, sheep, horses and donkeys (Cosyns et al. 2005b). Larger mammals have a remarkable potential for seed dispersal, with approximately 1200000 seeds per individual per summer calculated for both cattle and horses in a coastal dune landscape in Belgium (Cosyns et al. 2005a), up to 2600000 seeds per year for cattle in the Netherlands (Mouissie et al. 2005b), and an estimated 1510 seeds per square metre per year deposited by grazing cattle in a Mediterranean wooded pasture (Malo et al. 
128 2000). As well as seeds being adapted for endozoochory, ungulates have been found to selectively forage

129 flowers and fruits above leaves (Hulber et al. 2005). Like transportation in fur, germinable seeds in dung also 130 contain species with a range of other dispersal adaptations (Bruun et al. 2006, Couvreur et al. 2005a), and a 131 noteworthy proportion of the total species in grazed areas have been found in dung samples, between 21 and $13272 \%$ (Bakker et al. 2003, Cosyns et al. 2005a, Cosyns et al. 2005c, Mouissie et al. 2005b).

Not surprisingly, zoochorous seed dispersal is regarded as important for the diversity of the rural landscape, where animals can be described as 'moving pieces of habitat' (Fischer et al. 1996). In such fragmented landscapes, the negative impact of isolation can be partly explained by sheep fleece retention, whilst retention on cattle is significantly related to occupancy in grassland specialists (Adriaens et al. 2007). Both dung and fur are important vectors of specialist and red-listed species (Eichberg et al. 2007, Fischer et al. 1996, Wessels et al. 2008), and epi- and endozoochory have been found to complement one another with regards to species dispersed (Couvreur et al. 2005a). The contents of Table 1 also indicate a complimentarity between grazing animals in the grasslands, with the larger mammals transporting a large number of seeds internally, but sheep transporting far more on their coats than other animals. Investigations into both epi- and endozoochory in natural conditions have shown that each study herbivore species transports the diaspores of plant species not transported by any other herbivore study species (Cosyns et al. 2005a, Couvreur et al. 2004a). The act of dispersal can also be complimentary, where cow dung has a large total seed content, it is deposited in concentrated heaps in areas where the animal has been ruminating, whilst sheep drop numerous small dung pellets whilst in motion (Mitlacher et al. 2002). Bruun and Fritzbøger (2002) state that more two-thirds of plant species growing in Danish semi-natural grasslands today can be transported by cattle and sheep combined. 
154 Despite this great potential for dispersal in the rural landscape, very little is now realised. In Early Modern

155 Europe, three-field rotation systems between pasture and arable cropping were the norm (Clout 1999). Villages

156 in many countries employed an in-outfield system, where livestock grazed communal land during the summer,

157 and enclosed on arable land post-harvest (Uhlig 1961, Whyte 1999). Fences between arable fields were also rare

158 due to the labour-costs involved (Bruun et al. 2002). These practices would have allowed for free dispersal of

159 plant species at the landscape scale, but by the start of the nineteenth century, the enclosure movement had swept

160 across Europe. Communally regulated systems were gradually eliminated and commonlands were abolished

161 (Clout 1999). The past system involved a lot of mixed grazing, though is now a much less common practice, and

162 livestock often spend the whole season grazing the same small pasture. Together with the destruction and

163 abandonment of grassland habitats in the twentieth century, the changes in livestock management practices over

164 time have taken their toll on grassland plant species. The more light-demanding a species is, there more likely it

165 is to be dispersed epi- or endozoochorously, or both (Ozinga et al. 2004), but these are the dispersal vectors

166 which are being denied since the modernisation of agriculture, and the species which are now most threatened.

Transhumance, the seasonal movement of livestock between pastures was widespread for centuries (Whyte 1999), facilitating the movement of seeds between landscapes and even countries. This has also been progressively abandoned as a result of economic development (Manzano et al. 2006). Studies of two of the few remaining transhumance ovine drives, in Germany and in Spain found that experimentally attached seeds were still attached at the end of the experiment, after travelling over $100 \mathrm{~km}$ and $400 \mathrm{~km}$ respectively (Fischer et al. 1996, Manzano et al. 2006). The reintroduction of transhumance and in-out land systems in Europe is unlikely 
174 due to land ownership issues, but zoochorous seed dispersal can still occur over longer distances through the 175 transportation of grazing animals between isolated nature reserves (Couvreur et al. 2004a, Wessels et al. 2008).

176 Dispersal via grazing animals certainly has the potential for LDD, but only if the animals are allowed to move 177 long distances.

181 Changing practices within existing field systems could also benefit dispersal. As mentioned in section 2.1.4, different herbivores complement each other with regards to seed dispersal methods and seeds transported. The type of disturbances caused by different grazers can also be complimentary. Dung deposits by cows can give an overly strong nutrient stimulus, leading to taller vegetation and light limitation if grazing pressure is not maintained (Bakker et al. 2003). When it comes to pure physical disturbance, cows are preferred to smaller herbivores because their large size leads to more disturbance and therefore gaps in the sward, benefitting colonisation (Pywell et al. 2007). Herbivore diversity can lead to both additive and compensatory effects (Ritchie et al. 1999), whereby different animals can selectively graze the same or different plant species. Loucougaray et al. (2004) found that mixed grazing of cattle and horses in a French dune system yielded a higher species richness than monospecific grazing due to a combination of additive and compensatory effects. A metastudy of management in semi-natural grasslands (Stewart et al. 2008) found that grazing stock was less important than grazing intensity for species richness. Historical records can be used to find out past grazing practices (Bender et al. 2005b, Dahlström 2006), so the possibility exists to recreate conditions which can aid dispersal and diversity. The combination of complimentarity in disturbances, seeds dispersed and grazing behaviour between different grazers suggests that an increase in grazer diversity in semi-natural landscapes, at an appropriate density, would be of benefit for conservation. 


\subsection{Traditional haymaking}

In order to feed livestock through the winter, it is necessary to provide hay. From Dahlström (2006), one can intensification.

Haycutting is well known to result in high species richness (Hansson et al. 2000, Kull et al. 1991, Mitlacher et al. 2002), which is usually attributed to an increased light availability following cutting, which positively affects grassland specialists. Dispersal is benefitted quite simply because more seeds are available for dispersal, as in contrast to in pastoral fields, meadow plants are allowed to complete their reproductive cycle undisturbed, with $95 \%$ of plants having matured at the traditional hay-cut date in mid-August, increasing to $100 \%$ if management was left as late as mid-September (Dahlström et al. 2008).Williams (1984) states that when the widespread and abundant Juncus are excluded, haycutting in October instead of September doubles the seed set. The act of haycutting itself can positively affect dispersal of anemochorous (wind-dispersed) seeds, with Rhinanthus minor dispersal found to benefit from this management technique (Coulson et al. 2001). one $21 \mathrm{~kg}$ hay bale from a traditionally managed meadow in England (Smith et al. 1996). Edwards and Younger 
219 in the meadow were represented, despite the early hay cut date in early July. Traditional haymaking is another 220 practice which has declined during modern times, whereas previously hayseed was collected from the barns 221 where the hay was stored and distributed on meadows, the import of commercial grassland seed and even roughage (Bruun et al. 2002, Poschlod et al. 1998) has reduced the dispersal potential of haymaking. The mechanisation of haymaking has also meant that the process takes less time, and therefore finishes earlier now than earlier in the twentieth century, also affecting seed set. Summing the maximum area of meadow in Dahlström's (2006) four parishes between 1620 and 1850 gives a total of 9332 ha, more than the 8300 ha of remaining meadowland in the whole of Sweden in 2008 (Jordbruksverket 2009).

\subsection{Motor vehicles}

\subsubsection{Private vehicles}

Whereas movement of grazing animals within and between landscapes has reduced through time, the invention of motor vehicles and agricultural machinery has introduced a new potential for seed dispersal in the rural landscape (see Table 1). Despite their apparent simplicity, studies looking at mud carried by cars since Clifford's (1959) work in Nigeria are few and far between. This mode does appear to be fairly effective at dispersing species through the landscape, though it is often referred to in relation to the transport of alien species (Lonsdale et al. 1994, Wace 1977). An experiment in three road tunnels in the Berlin area showed that of 204 species found, exactly half were non-native to the region, including 39 listed as problematic aliens worldwide, and five of particular concern in Germany (Von der Lippe et al. 2007). Despite their non-nativeness, over $70 \%$ of the total plant species and $98.5 \%$ of the seeds collected were part of the regional roadside flora, of which many of 
241 these species were found within $100 \mathrm{~m}$ of the tunnel entrances. Not surprisingly, all published motor vehicle 242 dispersal studies also state that most species transported are typical of local roadsides and ruderal land, though 243 correlations between species abundance in samples and roadsides are rarely found (Clifford 1959, Hodkinson et 244 al. 1997, Schmidt 1989, Wace 1977, Zwaenepoel et al. 2006). This is probably due to the negative relationship 245 between precipitation before sampling and seeds found (Zwaenepoel et al. 2006). From the tunnel experiment in 246 Berlin (Von der Lippe et al. 2007), it can be assumed that seeds of most roadside species will be picked up by 247 vehicles at some point during the year, and therefore that samples taken from vehicles driving mainly around the 248 rural landscape should have a higher fraction of plants from rural habitats, and fewer aliens. Obviously no plant 249 species has evolved to disperse via motor vehicles, but Zwaenepoel et al. (2006) found a significantly higher 250 proportion of seeds with persistent seed banks were dispersed by this agent, indicating that this method can aid 251 dispersal of species through space which are traditionally dispersed through time. The insides of cars are also 252 thought to contain a large number of seeds (Wace 1977), which could then become attached to the occupants for 253 later dispersal in the landscape.

2.3.2. Agricultural machinery

Mowing machinery operating in species-rich meadows has also been found to be an effective dispersal agent, where small subsamples of material collected post-mowing contained 27 of 52 species found in the meadow system (Strykstra et al. 1997). Cultivation machinery has also been shown to transport seeds between arable fields (Mayer 2000), though this would be of limited use in semi-natural grasslands. However, tractors were found to transport seeds the furthest due to the limited contact with the earth, and these vehicles are used in meadows and on pastures, where the physical disturbance can promote the generation of new seedlings, an effect documented on grassland with other heavy vehicles (Hirst et al. 2003). 
267 As mentioned earlier, regularly managed road verges can act as remnant habitats for grassland specialists. They have also been shown to allow colonisation of such species (Kiviniemi et al. 1999), especially with regular mowing (Milberg et al. 1994). It has been argued that grassland plants use road and railway verges for dispersal (Tikka et al. 2001), however a modelling exercise has calculated that the rates of migration along these habitats are only in the order of a few metres per year, even in the widest corridors (vanDorp et al. 1997). The latter study however only considered wind dispersal, and therefore predicted rates could be somewhat increased if vehicles were included, though better data are needed. Road and railway verges should have the same mowing regimes as ancient meadows. This would maintain species richness and allow plants to reach the reproductive stage (Jantunen et al. 2007), in turn allowing the effectiveness of motor vehicles to disperse grassland species to aid in grassland connectivity. Australia (Mount et al. 2009) has shown the capacity for clothing to disperse seeds, both native and alien, where 207 clothing samples yielded almost 25000 seeds of 70 taxa. The paper also contains a useful summary of the few published clothing dispersal studies, which is dominated by work from the Southern Hemisphere focussing on aliens (Healy 1943, Whinam et al. 2005). There is a clear absence of recent work from Europe quantifying the number of seeds and species dispersed with humans, which is limited to Clifford's (1956) investigation of his 
shoes and those of his colleagues, which were found to contain seeds of 44 species representing a range of dispersal adaptations, and Woodruffe-Peacock (1918), who identified mud from boots, as well as clothing and hair as the sources of seeds for a number of species colonising a newly created fox covert. There have been few attempts to quantify dispersal distances of seeds attached to humans, but seeds of three species in Costa Rica were calculated to have mean dispersal distances of 4.6-2420m on cotton trousers and shirts, depending on habitat (Bullock et al. 1977), and two species of Brassica were regularly found to remain attached to the mud on boots after $5 \mathrm{~km}$ walking, which was almost fifty times further than the maximum value calculated for wind dispersal, which is their primary vector (Wichmann et al. 2009).

Mechanisation of agriculture has meant there are fewer humans working in the landscape, but the potential for dispersal by recreational walkers (and ecologists) remains. Many people walking through the modern landscape are accompanied by dogs, and these can also be effective dispersers of seeds (Graae 2002, Heinken 2000). Seeds transported on humans and their pets will also travel in cars and other modes of transport, increasing dispersal distances further. Recreational horse-riding combines the effectiveness of equine endozoochory with man's freedom to move throughout the landscape, although like motor vehicles, this has also been linked to the spread of alien species (Törn et al. 2010, Wells et al. 2007).

It would be difficult to incorporate seed dispersal directly by humans into any conservation plans, however 'Freedom to Roam' public access rights such as those enjoyed in the Nordic countries would be expected to benefit dispersal by this route, as well as a general promotion of recreation in semi-natural grasslands. Löfgren and Jerling (2002) found that islands in the Stockholm archipelago with a longer history of recreation exhibited a higher rate of immigration than those where recreation began more recently. 
310 3. The role of HMD in the restoration of abandoned or converted grassland

\section{3.1.HMD and Restoration}

312 The successful restoration of former grasslands has a positive impact on local biodiversity, and should also 313 reduce the isolation of remaining ancient grassland fragments. A lot of research has been carried out on this 314 subject, although a recent and comprehensive review is lacking (but see Walker et al. 2004 for a UK specific 315 review of restoration from former arable fields). A common conclusion is that restoration of species rich 316 grassland communities is seed limited. Seeds of grassland species are often transient, and therefore restoration of 317 abandoned semi-natural grasslands in Europe cannot rely upon regeneration via the seed bank (Bakker et al.

318 1996, Bossuyt et al. 2008, Buisson et al. 2006, Edwards et al. 1999, Kalamees et al. 1998, Mitlacher et al. 2002,

319 Wagner et al. 2003). Seed banks in grasslands on former arable fields are especially depleted (Bekker et al. 1997,

320 Graham et al. 1988, Hutchings et al. 1996), and therefore propagule additions are required to aid colonisation of 321 desirable species (Kardol et al. 2008, Lepš et al. 2007, Lindborg 2006, Öster et al. 2009, Pykälä 2003, Pywell et 322 al. 2002, but seeRuprecht 2006, Smith et al. 2002, Stampfli et al. 1999).

Thus it is important that any restoration management focuses on dispersal, and just as with the remaining seminatural grasslands, management inspired by traditional agricultural methods can be very effective, especially the use of mixed grazing, and the movement of livestock between pastures. If it is impossible or unfeasible to move the animals and the seeds they carry, then the high quantities of seeds in dung would suggest that the redistribution of manure to target areas might help species dispersal between grazing areas. However, seedling establishment in the field after endozoochory is often found to be lower than that measured in the greenhouse (Malo et al. 1995, Mouissie et al. 2005b, Pakeman et al. 2009). Kohler et al. (2006, 2004) similarly found a relatively negligible impact of dunging on colonisation compared to other disturbances such as mowing and 
332 physical disturbance. A study based on rabbits, however, found that dung contributes to seed bank build-up

333 (Pakeman et al. 1999), and even seeds with transient banks have been found in the soil below decomposed dung

334 patches (Dai 2000). It may therefore be that the positive effects of manuring take time to manifest. The storage

335 of dung has a negative impact on germinability (Edwards et al. 2006, Mayer 2000), and samples deposited can

336 only be as species rich as what was eaten (Edwards et al. 2006), so in order for such a measure to work best,

337 manure samples would have to be collected during summer grazing in species-rich pastures and redistributed

338 directly to target areas. In a similar vein, the spreading of hay from species rich meadows (Donath et al. 2007,

339 Edwards et al. 2007, Kiehl et al. 2006) and even the transplantation of turf from nearby grasslands (Pärtel et al.

340 1998) have been found to aid with the reestablishment of species rich target communities in former species-rich

341 grasslands.

Restoration management can also form an economic benefit. Sowing species rich seed mixtures on former arable

fields gave significantly higher hay yields than did the standard seed mixture recommended for agri-environment schemes, whilst also creating a vegetation layer resembling the species-rich target community (Bullock et al. 2001, Bullock et al. 2007). The perceived incompatibility of agricultural and environmental goals has recently been disputed. Kumm (2004) suggests how recreating large continuous pastoral mosaics can be of economic benefit, but (as Kumm also points out) it could equally be useful for conservation. Propagules could be dispersed by livestock over much larger areas than in modern, small-field systems, and areas formerly under arable land use or abandoned would benefit from the increased local species pool to aid in their restoration. Even if individual farmers could open up their pastures to connect those of different histories, the dispersal of grassland specialists in the landscape would be benefitted, although there would be a danger of dispersing more non-target 
356

357

could have implications for agro-environment subsidies and organic certification. If there are no direct financial incentives for restoration management which aids dispersal, increasing subsidies is an option (Zechmeister et al. 2003), as is the alignment of conservation with other benefits to society such as flood protection, tourism and health (Sutherland 2004). An increase in tourism would bring more people with more dogs and horses and therefore more seeds, but this could also mean more aliens.

Whichever methods are employed, restoration to target community takes a considerable amount of time, with estimations in the order of decades, depending on initial conditions (Gibson et al. 1992, Klimeš et al. 2000, Mitlacher et al. 2002, Smith et al. 2000). This more intensive management and directed dispersal must therefore continue for some time to ensure the dispersal of target species to the site, and progress should be regularly monitored to assess the success of the restoration work and adapt it to suit local conditions.

\section{Dispersal and Conservation on the landscape scale}

Throughout this review, the importance of considering the landscape has been implicit, from the importance of historical landscape configuration and the value of remnant habitats and linear corridors, to the potential for long-distance dispersal in semi-natural grasslands, and the movement of hay, manure and livestock between grassland habitats across the landscape which can aid it. All the human mediated dispersal vectors discussed show the potential for LDD, and understanding the geographical context of dispersal is vital if we are to facilitate it for conservational goals. 
378 Experiments into grassland restoration from arable land in Britain are generally characterised by small blocks of

379 land within one field (e.g. Pywell et al. 2007, Smith et al. 2002), concentrating on the effects of different

380 management types at the expense of considering the landscape. The importance of considering the landscape is

381 highlighted by a rare example of spontaneous restoration of former arable fields, where it was the presence of

382 source habitats in the surrounding landscape which was most important for the successful recolonisation of

383 grassland specialists (Ruprecht 2006).

384

385 There is also little doubt that the facilitation of dispersal by the village scale grazing regimes and national and

386 international livestock drives contributed to the high species richness of these grasslands across Europe after the

387 elimination of native large herbivores. Although such management cannot easily be brought back, the movement

388 of livestock between fragmented pastures shows that modern management can still assist seed dispersal over

389 large distances (Couvreur et al. 2004a), and larger pastures can be of both an environmental and economic

390 benefit (Kumm 2004). Other conservation measures based upon historical landscape scale dispersal, such as hay

391 spreading (Edwards et al. 2007), hay exchange (Mayer 2000), and possibly even fresh manure exchange and

392 spreading could also be beneficial, and should be relatively simple to organise.

393

394

395

5. Conclusions and further research

396 
397 In this review, I have highlighted the enormous potential for human-mediated seed dispersal of grassland plant 398 species in Europe. The studies summarised in Table 1 show that HMD can be an important in terms of both 399 number of seeds and species. It is clear, however, that modern land-use change and agricultural intensification 400 has negatively affected this potential. In order to preserve, conserve and restore high species richness in semi401 natural grassland landscapes, it is therefore important to draw inspiration from past land use and its dispersal 402 vectors, but equally important is not to overlook the potential of those that modern life and agriculture has 403 introduced. A great deal of research into human-mediated seed dispersal has been done during the past decade, 404 but there is still more to be done, and in the case of semi-natural grasslands, it is vital that both agricultural 405 history and the landscape scale are considered.

The research and conservation of European semi-natural grasslands should be considered at the landscape scale. Empirical experiments at the landscape scale are generally lacking (de Blois et al. 2002, Hanski et al. 2003, Harrison et al. 1999), particularly in relation to semi-natural grasslands. Research into endo- and exozoochory in livestock is generally limited to a few research groups, and therefore more experiments should take place in semi-natural landscapes across Europe, looking to quantify both the potential and the realised transportation by these routes. Experiments looking at more modern dispersal agents such as humans and motor vehicles are very rare, though these can be seen as the agents which have the free access to the landscape which animals no longer do. Long distance dispersal events can often be caused by non-standard means (Higgins et al. 2003), and there are several examples of this in this review. Measuring the seed dispersal that actually happens should therefore be a priority, removing the bias of how we think seeds should migrate instead of how they do migrate. The ability for a non-adapted seed to survive digestion is not useful if the seeds are never eaten. Once data have been collected on the many routes of seed dispersal through the semi-natural landscape, robust, landscape scale models can be built. Landscape scale empirical studies require a great deal of time and resources, but they are 
422 Finally, management practices should reflect what the research has found out, and conservation and restoration 423 should be regularly monitored, modified and reported, in line with evidence-based conservation (Sutherland et 424 al. 2004). Species-rich semi-natural grasslands took centuries to develop, and it is only through continual, long 425 term and appropriate management that they can be conserved and restored for the future.

426

427 Acknowledgements

428

429

My thanks go to Sara Cousins and Ove Eriksson for their helpful comments on previous versions of the

430 manuscript.

\section{References}

433
Adriaens, D., Honnay, O. \& Hermy, M. 2007. Does seed retention potential affect the distribution of plant species in highly fragmented calcareous grasslands? Ecography 30: 505-514.

Adriaens, D., Honnay, O. \& Hermy, M. 2006. No evidence of a plant extinction debt in highly fragmented calcareous grasslands in Belgium. Biological Conservation 133: 212-224.

Bakker, E.S. \& Olff, H. 2003. Impact of different-sized herbivores on recruitment opportunities for subordinate herbs in grasslands. Journal of Vegetation Science 14: 465-474.

Bakker, J.P., Bakker, E.S., Rosén, E., Verweij, G.L. \& Bekker, R.M. 1996. Soil seed bank composition along a gradient from dry alvar grassland to Juniperus shrubland. Journal of Vegetation Science 165-176.

Bekker, R.M., Verweij, G.L., Smith, R.E.N., Reine, R., Bakker, J.P. \& Schneider, S. 1997. Soil seed banks in European grasslands: does land use affect regeneration perspectives? Journal of Applied Ecology 34: 1293-1310.

Bender, O., Boehmer, H.J., Jens, D. \& Schumacher, K.P. 2005a. Analysis of land-use change in a sector of Upper Franconia (Bavaria, Germany) since 1850 using land register records. Landscape Ecology 20: 149-163. 
445

446

447

448

449

450

451

452

453

454

455

456

457

458

459

460

461

462

463

464

465

466

467

468

469

470

471

472

473

474

475

476
Bender, O., Boehmer, H.J., Jens, D. \& Schumacher, K.P. 2005b. Using GIS to analyse long-term cultural landscape change in Southern Germany. Landscape and Urban Planning 70: 111-125.

Bossuyt, B. \& Honnay, O. 2008. Can the seed bank be used for ecological restoration? An overview of seed bank characteristics in European communities. Journal of Vegetation Science 19: 875-884.

Bruun, H.H. \& Fritzbøger, B. 2002. The past impact of livestock husbandry on dispersal of plant seeds in the landscape of Denmark. Ambio 31: 425-431.

Bruun, H.H. \& Poschlod, P. 2006. Why are small seeds dispersed through animal guts: large numbers or seed size per se? Oikos 113: 402-411.

Buisson, E., Dutoit, T., Torre, F., Römermann, C. \& Poschlod, P. 2006. The implications of seed rain and seed bank patterns for plant succession at the edges of abandoned fields in Mediterranean landscapes. Agriculture Ecosystems \& Environment 115: 6-14.

Bullock, J.M., Pywell, R.F., Burke, M.J.W. \& Walker, K.J. 2001. Restoration of biodiversity enhances agricultural production. Ecology Letters 4: 185-189.

Bullock, J.M., Pywell, R.F. \& Walker, K.J. 2007. Long-term enhancement of agricultural production by restoration of biodiversity. Journal of Applied Ecology 44: 6-12.

Bullock, S.H. \& Primack, R.B. 1977. Comparative experimental study of seed dispersal on animals. Ecology 58: 681-686.

Chýlová, T. \& Münzbergová, Z. 2008. Past land use co-determines the present distribution of dry grassland plant species. Preslia 80: 183-198.

Clifford, H.T. 1959. Seed dispersal by motor vehicles. Journal of Ecology 47: 311-315.

Clifford, H.T. 1956. Seed dispersal on footwear. Proceedings of the Botanical Society of the British Isles 2: 129131.

Clout, H. 1999. Rural Europe since 1500: Areas of innovation and change. In: Butlin, R.A. \& Dodgshon, R.A. (eds.) An historical geography of Europe, pp. 225-242. Oxford University Press, Oxford.

Cosyns, E., Bossuyt, B., Hoffmann, M., Vervaet, H. \& Lens, L. 2006. Seedling establishment after endozoochory in disturbed and undisturbed grasslands. Basic and Applied Ecology 7: 360-369.

Cosyns, E., Claerbout, S., Lamoot, I. \& Hoffmann, M. 2005a. Endozoochorous seed dispersal by cattle and horse in a spatially heterogeneous landscape. Plant Ecology 178: 149-162.

Cosyns, E., Delporte, A., Lens, L. \& Hoffmann, M. 2005b. Germination success of temperate grassland species after passage through ungulate and rabbit guts. Journal of Ecology 93: 353-361.

Cosyns, E. \& Hoffmann, M. 2005c. Horse dung germinable seed content in relation to plant species abundance, diet composition and seed characteristics. Basic and Applied Ecology 6: 11-24. 
477

478

479

480

481

482

483

484

485

486

487

488

489

490

491

492

493

494

495

496

497

498

499

500

501

502

503

504

505

506

507

508

509
Coulson, S.J., Bullock, J.M., Stevenson, M.J. \& Pywell, R.F. 2001. Colonization of grassland by sown species: dispersal versus microsite limitation in responses to management. Journal of Applied Ecology 38: 204-216.

Cousins, S.A.O. 2006. Plant species richness in midfield islets and road verges - the effect of landscape fragmentation. Biological Conservation 127: 500-509.

Cousins, S.A.O., Eriksson, A. \& Franzén, D. 2002. Reconstructing past land use and vegetation patterns using palaeogeographical and archaeological data - a focus on grasslands in Nynäs by the Baltic Sea in south-eastern Sweden. Landscape and Urban Planning 61: 1-18.

Cousins, S.A.O. \& Eriksson, O. 2001. Plant species occurrences in a rural hemiboreal landscape: effects of remnant habitats, site history, topography and soil. Ecography 24: 461-469.

Cousins, S.A.O. \& Lindborg, R. 2008. Remnant grassland habitats as source communities for plant diversification in agricultural landscapes. Biological Conservation 141: 233-240.

Couvreur, M., Christiaen, B., Verheyen, K. \& Hermy, M. 2004a. Large herbivores as mobile links between isolated nature reserves through adhesive seed dispersal. Applied Vegetation Science 7: 229-236.

Couvreur, M., Cosyns, E., Hermy, M. \& Hoffmann, M. 2005a. Complementarity of epi- and endozoochory of plant seeds by free ranging donkeys. Ecography 28: 37-48.

Couvreur, M., Vandenberghe, B., Verheyen, K. \& Hermy, M. 2004b. An experimental assessment of seed adhesivity on animal furs. Seed Science Research 14: 147-159.

Couvreur, M., Verheyen, K. \& Hermy, M. 2005b. Experimental assessment of plant seed retention times in fur of cattle and horse. Flora 200: 136-147.

Dahlström, A. 2006. Betesmarker, djurantal och betestryck 1620-1850. Naturvårdsaspekter på historisk beteshävd i Syd- och Mellansverige. Centrum för Biologisk Mångfald, Uppsala.

Dahlström, A., Cousins, S.A.O. \& Eriksson, O. 2006. The history (1620-2003) of land use, people and livestock, and the relationship to present plant species diversity in a rural landscape in Sweden. Environment and History 12: $191-212$.

Dahlström, A., Lennartsson, T., Wissman, J. \& Frycklund, I. 2008. Biodiversity and Traditional Land Use in South-Central Sweden: The Significance of Management Timing. Environment and History 14: 385-403.

Dahlström, A., Rydin, H. \& Borgegård, S.-O. published online. Remnant habitats for grassland species in an abandoned Swedish agricultural landscape. Applied Vegetation Science.

Dai, X.B. 2000. Impact of cattle dung deposition on the distribution pattern of plant species in an alvar limestone grassland. Journal of Vegetation Science 11: 715-724.

de Blois, S., Domon, G. \& Bouchard, A. 2002. Landscape issues in plant ecology. Ecography 25: 244-256.

de Pablos, I. \& Peco, B. 2007. Diaspore morphology and the potential for attachment to animal coats in Mediterranean species: an experiment with sheep and cattle coats. Seed Science Research 17: 109-114. 
510 Donath, T.W., Bissels, S., Hölzel, N. \& Otte, A. 2007. Large scale application of diaspore transfer with plant material in restoration practice - Impact of seed and microsite limitation. Biological Conservation 138: 224-234.

512 Edwards, A.R., Mortimer, S.R., Lawson, C.S., Westbury, D.B., Harris, S.J., Woodcock, B.A. \& Brown, V.K. 513 2007. Hay strewing, brush harvesting of seed and soil disturbance as tools for the enhancement of botanical 514 diversity in grasslands. Biological Conservation 134: 372-382.

515

516

517
Edwards, A.R. \& Younger, A. 2006. The dispersal of traditionally managed hay meadow plants via farmyard manure application. Seed Science Research 16: 137-147.

Edwards, G.R. \& Crawley, M.J. 1999. Herbivores, seed banks and seedling recruitment in mesic grassland. Journal of Ecology 87: 423-435.

Ehrlén, J., Münzbergová, Z., Diekmann, M. \& Eriksson, O. 2006. Long-term assessment of seed limitation in plants: results from an 11-year experiment. Journal of Ecology 94: 1224-1232.

Eichberg, C., Storm, C. \& Schwabe, A. 2007. Endozoochorous dispersal, seedling emergence and fruiting success in disturbed and undisturbed successional stages of sheep-grazed inland sand ecosystems. Flora 202: 326.

Eriksson, Å. \& Eriksson, O. 1997. Seedling recruitment in semi-natural pastures: the effects of disturbance, seed size, phenology and seed bank. Nordic Journal of Botany 17: 469-482.

Eriksson, O., Wikström, S., Eriksson, Å. \& Lindborg, R. 2006. Species-rich Scandinavian grasslands are inherently open to invasion. Biological Invasions 8: 355-363.

Fischer, S.F., Poschlod, P. \& Beinlich, B. 1996. Experimental studies on the dispersal of plants and animals on sheep in calcareous grasslands. Journal of Applied Ecology 33: 1206-1222.

Foster, D., Swanson, F., Aber, J., Burke, I., Brokaw, N., Tilman, D. \& Knapp, A. 2003. The importance of landuse legacies to ecology and conservation. Bioscience 53: 77-88.

Franzén, D. \& Eriksson, O. 2003. Patch distribution and dispersal limitation of four plant species in Swedish semi-natural grasslands. Plant Ecology 166: 217-225.

Fuller, R.M. 1987. The Changing Extent and Conservation Interest of Lowland Grasslands in England and Wales: A Review of Grassland Surveys 1930-84. Biological Conservation 40: 281-300.

Gibson, C.W.D. \& Brown, V.K. 1992. Grazing and vegetation change: deflected of modified succession? Journal of Applied Ecology 29: 120-131.

Graae, B.J. 2002. The role of epizoochorous seed dispersal of forest plant species in a fragmented landscape. Seed Science Research 12: 113-120.

Graham, D.J. \& Hutchings, M.J. 1988. A field investigation of germination from the seed bank of a chalk grassland ley on former arable land. Journal of Applied Ecology 25: 253-263.

Gross, K.L., Mittelbach, G.G. \& Reynolds, H.L. 2005. Grassland invasibility and diversity: Responses to nutrients, seed input, and disturbance. Ecology 86: 476-486. 
544 Gustavsson, E., Lennartsson, T. \& Emanuelsson, M. 2007. Land use more than 200 years ago explains current grassland plant diversity in a Swedish agricultural landscape. Biological Conservation 138: 47-59.

546 Hanski, I. 1999. Metapopulation Ecology. Oxford University Press, Oxford.

547 Hanski, K. \& Ovaskainen, O. 2003. Metapopulation theory for fragmented landscapes. Theoretical Population $548 \quad$ Biology 64: 119-127.

549 Hansson, M. \& Fogelfors, H. 2000. Management of a semi-natural grassland; results from a 15-year-old 550 experiment in southern Sweden. Journal of Vegetation Science 11: 31-38.

551 Harrison, S. \& Bruna, E. 1999. Habitat fragmentation and large-scale conservation: what do we know for sure? 552 Ecography 22: 225-232.

553 Healy, A.J. 1943. Plant dispersal by human activity. Nature 151: 140.

554 Heinken, T. 2000. Dispersal of plants by a dog in a decidiuous forest. Botanisches Jahrbücher für Systematik, 555 Pflanzengeschichte und Pflanzengeographyraphie 122: 449-467.

Helm, A., Hanski, I. \& Pärtel, M. 2006. Slow response of plant species richness to habitat loss and fragmentation. Ecology Letters 9: 72-77.

Higgins, S.I., Nathan, R. \& Cain, M.L. 2003. Are long-distance dispersal events in plants usually caused by 559 nonstandard means of dispersal? Ecology 84: 1945-1956.

560 Hirst, R.A., Pywell, R.F., Marrs, R.H. \& Putwain, P.D. 2003. The resistance of a chalk grassland to disturbance. 561 Journal of Applied Ecology 40: 368-379.

Hodkinson, D.J. \& Thompson, K. 1997. Plant dispersal: the role of man. Journal of Applied Ecology 34: 14841496.

Hovd, H. \& Skogen, A. 2005. Plant species in arable field margins and road verges of central Norway.

565 Agriculture Ecosystems \& Environment 110: 257-265.

Hulber, K., Ertl, S., Gottfried, M., Reiter, K. \& Grabherr, G. 2005. Gourmets or gourmands? Diet selection by

Hutchings, M.J. \& Booth, K.D. 1996. Studies on the feasibility of re-creating chalk grassland vegetation on ex- 
575

576

577

578

579

580

581

582

583

584

585

586

587

588

589

590

591

592

593

594

595

596

597

598

599

600

601

602

603

604

605

606

607

608
Johansson, L.J., Hall, K., Prentice, H.C., Ihse, M., Reitalu, T., Sykes, M.T. \& Kindström, M. 2008. Semi-natural grassland continuity, long-term land-use change and plant species richness in an agricultural landscape on Oland, Sweden. Landscape and Urban Planning 84: 200-211.

Jordbruksverket 2009. Betesmarker och slåtterängar - Markklasser. URL:

http://www.jordbruksverket.se/download/18.5aec661121e261385280003189/Betesmarker+och+sl\%C3\%A5tter \%C3\%A4ngar+-+markklasser+2008.pdf

Kalamees, R. \& Zobel, M. 1998. Soil seed bank composition in different successional stages of a species rich wooded meadow in Laelatu, western Estonia. Acta Oecologica-International Journal of Ecology 19: 175-180.

Kardol, P., Van der Wal, A., Bezemer, T.M., de Boer, W., Duyts, H., Holtkamp, R. \& Van der Putten, W.H. 2008. Restoration of species-rich grasslands on ex-arable land: Seed addition outweighs soil fertility reduction. Biological Conservation 141: 2208-2217.

Kiehl, K., Thormann, A. \& Pfadenhauer, J. 2006. Evaluation of initial restoration measures during the restoration of calcareous grasslands on former arable fields. Restoration Ecology 14: 148-156.

Kiviniemi, K. 1996. A study of adhesive seed dispersal of three species under natural conditions. Acta Botanica Neerlandica 45: 73-83.

Kiviniemi, K. \& Eriksson, O. 1999. Dispersal, recruitment and site occupancy of grassland plants in fragmented habitats. Oikos 86: 241-253.

Klimeš, L., Dančák, M., Hájek, M., Jongepierová, I. \& Kučera, T. 2001. Scale-dependent biases in species counts in a grassland. Journal of Vegetation Science 12: 699-704.

Klimeš, L., Jongepierová, I. \& Jongepier, J.W. 2000. The effect of mowing on a previously abandoned meadow: a ten-year experiment. Priroda Praha 17: 7-24.

Kohler, F., Gillet, F., Gobat, J.M. \& Buttler, A. 2006. Effect of cattle activities on gap colonization in mountain pastures. Folia Geobotanica 41: 289-304.

Kohler, F., Gillet, F., Gobat, J.M. \& Buttler, A. 2004. Seasonal vegetation changes in mountain pastures due to simulated effects of cattle grazing. Journal of Vegetation Science 15: 143-150.

Kuiters, A.T. \& Huiskes, H.P.J. Potential of endozoochorous seed dispersal by sheep in calcareous grasslands: correlations with seed traits. Applied Vegetation Science 13: 163-172.

Kull, K. \& Zobel, M. 1991. High species richness in an Estonian wooded meadow. Journal of Vegetation Science 2: 715-718.

Kumm, K.-I. 2004. Does re-creation of extensive pasture-forest mosaics provide an economically sustainable way of nature conservation in Sweden's forest dominated regions? Journal for Nature Conservation 12: 213218.

Lepš, J., Doležal, J., Bezemer, T.M., Brown, V.K., Hedlund, K., Igual, A.M., Jörgensen, H.B., Lawson, C.S., Mortimer, S.R., Peix Geldart, A., Rodríguez Barrueco, C., Santa Regina, I., Šmilauer, P. \& van der Putten, W.H. 
609 2007. Long-term effectiveness of sowing high and low diversity seed mixtures to enhance plant community

610 development on ex-arable fields. Applied Vegetation Science 10: 97-110.

611 Lindborg, R. 2006. Recreating grasslands in Swedish rural landscapes - effects of seed sowing and management 612 history. Biodiversity and Conservation 15: 957-969.

613 Lindborg, R. \& Eriksson, O. 2004. Historical landscape connectivity affects present plant species diversity.

614 Ecology 85: 1840-1845.

615 Löfgren, A. \& Jerling, L. 2002. Species richness, extinction and immigration rates of vascular plants on islands 616 in the Stockholm Archipelago, Sweden, during a century of ceasing management. Folia Geobotanica 37: $297-$ 617308.

618 Lonsdale, W.M. \& Lane, A.M. 1994. Tourist vehicles as vectors of weed seeds in Kakadu National Park, 619 Northern Australia. Biological Conservation 69: 277-283.

Loucougaray, G., Bonis, A. \& Bouzillé, J.B. 2004. Effects of grazing by horses and/or cattle on the diversity of coastal grasslands in western France. Biological Conservation 116: 59-71.

622

623

624

625

626

627

628

629

630

631

632

633

634

635

636

637

638

639

640

641

Luoto, M., Rekolainen, S., Aakkula, J. \& Pykälä, J. 2003. Loss of plant species richness and habitat connectivity in grasslands associated with agricultural change in Finland. Ambio 32: 447-452.

Malo, J.E., Jiménez, B. \& Suarez, F. 2000. Herbivore dunging and endozoochorous seed deposition in a Mediterranean dehesa. Journal of Range Management 53: 322-328.

Malo, J.E. \& Suárez, F. 1995. Establishment of pasture species on cattle dung: the role of endozoochorous seeds. Journal of Vegetation Science 6: 169-174.

Manzano, P. \& Malo, J.E. 2006. Extreme long-distance seed dispersal via sheep. Frontiers in Ecology and the Environment 4: 244-248.

Maurer, K., Durka, W. \& Stocklin, J. 2003. Frequency of plant species in remnants of calcareous grassland and their dispersal and persistence characteristics. In: pp. 307-316.

Mayer, F. 2000. Long distance dispersal of weed diaspores in agricultural landscapes- The Scheyern approach. Shaker, Aachen.

Milberg, P. \& Persson, T.S. 1994. Soil seed bank and species recruitment in road verge grassland vegetation. Annales Botanici Fennici 31: 155-162.

Mitlacher, K., Poschlod, P., Rosén, E. \& Bakker, J.P. 2002. Restoration of wooded meadows - a comparative analysis along a chronosequence on Öland (Sweden). Applied Vegetation Science 5: 63-73.

Mouissie, A.M., Lengkeek, W. \& van Diggelen, R. 2005a. Estimating adhesive seed-dispersal distances: field experiments and correlated random walks. Functional Ecology 19: 478-486.

Mouissie, A.M., Vos, P., Verhagen, H.M.C. \& Bakker, J.P. 2005b. Endozoochory by free-ranging, large herbivores: Ecological correlates and perspectives for restoration. Basic and Applied Ecology 6: 547-558. 
642 Mount, A. \& Pickering, C.M. 2009. Testing the capacity of clothing to act as a vector for non-native seed in 643 protected areas. Journal of Environmental Management 91: 168-179.

644 Münzbergová, Z. 2004. Effect of spatial scale on factors limiting species distributions in dry grassland 645 fragments. Journal of Ecology 92: 854-867.

646 Nathan, R. 2006. Long-distance dispersal of plants. Science 313: 786-788.

647 Nathan, R., Schurr, F.M., Spiegel, O., Steinitz, O., Trakhtenbrot, A. \& Tsoar, A. 2008. Mechanisms of long648 distance seed dispersal. Trends in Ecology \& Evolution 23: 638-647.

649 Öster, M., Ask, K., Cousins, S.A.O. \& Eriksson, O. 2009. Dispersal and establishment limitation reduces the 650 potential for successful restoration of semi-natural grassland communities on former arable fields. Journal of 651 Applied Ecology 46: 1266-1274.

Ozinga, W.A., Bekker, R.M., Schaminee, J.H.J. \& Van Groenendael, J.M. 2004. Dispersal potential in plant communities depends on environmental conditions. Journal of Ecology 92: 767-777.

Ozinga, W.A., Hennekens, S.M., Schaminee, J.H.J., Bekker, R.M., Prinzing, A., Bonn, S., Poschlod, P., Tackenberg, O., Thompson, K., Bakker, J.P. \& van Groenendael, J.M. 2005. Assessing the relative importance of dispersal in plant communities using an ecoinformatics approach. Folia Geobotanica 40: 53-67.

Pakeman, R.J., Digneffe, G. \& Small, J.L. 2002. Ecological correlates of endozoochory by herbivores.

Functional Ecology 16: 296-304.

659

660

661

662

663

664

665

666

667

668

669

670

671

672

673

674

675
Pakeman, R.J., Engelen, J. \& Attwood, J.P. 1999. Rabbit endozoochroy and seedbank build-up in an acidic grassland. Plant Ecology 145: 83-90.

Pakeman, R.J. \& Small, J.L. 2009. Potential and realised contribution of endozoochory to seedling establishment. Basic and Applied Ecology 10: 656-661.

Pärtel, M., Helm, A., Reitalu, T., Liira, J. \& Zobel, M. 2007. Grassland diversity related to the Late Iron Age human population density. Journal of Ecology 95: 574-582.

Pärtel, M., Kalamees, R., Zobel, M. \& Rosén, E. 1998. Restoration of species-rich limestone grassland communities from overgrown land: the importance of propagule availability. Ecological Engineering 10: 275286.

Pärtel, M., Mandla, R. \& Zobel, M. 1999. Landscape history of a calcareous (alvar) grassland in Hanila, western Estonia, during the last three hundred years. Landscape Ecology 14: 187-196.

Poschlod, P. \& Bonn, S. 1998. Changing dispersal processes in the central European landscape since the last ice age: an explanation for the actual decrease of plant species richness in different habitats? Acta Botanica Neerlandica 47: 27-44.

Poschlod, P. \& WallisDeVries, M.F. 2002. The historical and socioeconomic perspective of calcareous grasslands - lessons from the distant and recent past. Biological Conservation 104: 361-376.

Primack, R.B. \& Miao, S.L. 1992. Dispersal can limit local plant-distribution. Conservation Biology 6: 513-519. 
676

677

678

679

680

681

682

683

684

685

686

687

688

689

690

691

692

693

694

695

696

697

698

699

700

701

702

703

704

705

706

707

708

709

710

Pykälä, J. 2003. Effects of restoration with cattle grazing on plant species composition and richness of seminatural grasslands. Biodiversity and Conservation 12: 2211-2226.

Pywell, R.F., Bullock, J.M., Hopkins, A., Walker, K.J., Sparks, T.H., Burke, M.J.W. \& Peel, S. 2002.

Restoration of species-rich grassland on arable land: assessing the limiting processes using a multi-site experiment. Journal of Applied Ecology 39: 294-309.

Pywell, R.F., Bullock, J.M., Tallowin, J.B., Walker, K.J., Warman, E.A. \& Masters, G. 2007. Enhancing diversity of species-poor grasslands: an experimental assessment of multiple constraints. Journal of Applied Ecology 44: 81-94.

Ritchie, M.E. \& Olff, H. 1999. Herbivore diversity and plant dynamics: compensatory and additive effects. In: Olff, H., Brown, V.K. \& Drent, R.H. (eds.) Herbivores, between Plants and Predators. The 38th Symposium of the British Ecological Society, pp. 175-204. Blackwell Science, Oxford.

Römermann, C., Tackenberg, O. \& Poschlod, P. 2005. How to predict attachment potential of seeds to sheep and cattle coat from simple morphological seed traits. Oikos 110: 219-230.

Ruprecht, E. 2006. Successfully recovered grassland: A promising example from Romanian old-fields. Restoration Ecology 14: 473-480.

Schmidt, M., Sommer, K., Kriebitzsch, W.U., Ellenberg, H. \& von Oheimb, G. 2004. Dispersal of vascular plants by game in northern Germany. Part I: Roe deer (Capreolus capreolus) and wild boar (Sus scrofa). European Journal of Forest Research 123: 167-176.

Schmidt, W. 1989. Plant dispersal by motor cars. Vegetatio 80: 147-152.

Simmering, D., Waldhardt, R. \& Otte, A. 2006. Quantifying determinants contributing to plant species richness in mosaic landscapes: a single- and multi-patch perspective. Landscape Ecology 21: 1233-1251.

Smart, S.M., Bunce, R.G.H., Firbank, L.G. \& Coward, P. 2002. Do field boundaries act as refugia for grassland plant species diversity in intensively managed agricultural landscapes in Britain? Agriculture Ecosystems \& Environment 91: 73-87.

Smith, R.S., Pullan, S. \& Shiel, R.S. 1996. Seed shed in the making of hay from mesotrophic grassland in a field in northern England: Effects of hay cut date, grazing and fertilizer in a split-split-plot experiment. Journal of Applied Ecology 33: 833-841.

Smith, R.S., Shiel, R.S., Millward, D. \& Corkhill, P. 2000. The interactive effects of management on the productivity and plant community structure of an upland meadow: an 8-year field trial. Journal of Applied Ecology 37: 1029-1043.

Smith, R.S., Shiel, R.S., Millward, D., Corkhill, P. \& Sanderson, R.A. 2002. Soil seed banks and the effects of meadow management on vegetation change in a 10-year meadow field trial. Journal of Applied Ecology 39: 279293.

Stampfli, A. \& Zeiter, M. 1999. Plant species decline due to abandonment of meadows cannot easily be reversed by mowing. A case study from the southern Alps. In: pp. 151-164. 
711

712

713

714

715

716

717

718

719

720

721

722

723

724

725

726

727

728

729

730

731

732

733

734

735

736

737

738

739

740

741

742

743

Stein, C., Auge, H., Fischer, M., Weisser, W.W. \& Prati, D. 2008. Dispersal and seed limitation affect diversity and productivity of montane grasslands. Oikos 117: 1469-1478.

Stewart, G.B. \& Pullin, A.S. 2008. The relative importance of grazing stock type and grazing intensity for conservation of mesotrophic 'old meadow' pasture. Journal for Nature Conservation 16: 175-185.

Strykstra, R.J., Verweij, G.L. \& Bakker, J.P. 1997. Seed dispersal by mowing machinery in a Dutch brook valley system. Acta Botanica Neerlandica 46: 387-401.

Sutherland, W.J. 2004. A blueprint for the countryside. In: pp. 230-238.

Sutherland, W.J., Pullin, A.S., Dolman, P.M. \& Knight, T.M. 2004. The need for evidence-based conservation. Trends in Ecology \& Evolution 19: 305-308.

Tikka, P.M., Högmander, H. \& Koski, P.S. 2001. Road and railway verges serve as dispersal corridors for grassland plants. Landscape Ecology 16: 659-666.

Tilman, D., May, R.M., Lehman, C.L. \& Nowak, M.A. 1994. Habitat destruction and the extinction debt. Nature 371: 65-66.

Törn, A., Siikamäki, P. \& Tolvanen, A. 2010. Can horse riding induce the introduction and establishment of alien plant species through endozoochory and gap creation? Plant Ecology 208: 235-244.

Uhlig, H. 1961. Old hamlets with infield and outfield systems in Western and Central Europe. Geografiska Annaler 43: 285-312.

vanDorp, D., Schippers, P. \& vanGroenendael, J.M. 1997. Migration rates of grassland plants along corridors in fragmented landscapes assessed with a cellular automation model. Landscape Ecology 12: 39-50.

Vera, F.W.M. 2000. Grazing Ecology and Forest History. CABI Publishing, Wallingford.

Von der Lippe, M. \& Kowarik, I. 2007. Long-distance dispersal of plants by vehicles as a driver of plant invasions. Conservation Biology 21: 986-996.

von Oheimb, G., Schmidt, M., Kriebitzsch, W.U. \& Ellenberg, H. 2005. Dispersal of vascular plants by game in northern Germany. Part II: Red deer (Cervus elaphus). European Journal of Forest Research 124: 55-65.

Wace, N. 1977. Assessment of dispersal of plant species - the car-borne flora in Canberra. Proceedings of the Ecological Society Australia 10: 167-186.

Wagner, M., Poschlod, P. \& Setchfield, R.P. 2003. Soil seed bank in managed and abandoned semi-natural meadows in Soomaa National Park, Estonia. Annales Botanici Fennici 40: 87-100.

Walker, K.J., Stevens, P.A., Stevens, D.P., Mountford, J.O., Manchester, S.J. \& Pywell, R.F. 2004. The restoration and re-creation of species-rich lowland grassland on land formerly managed for intensive agriculture in the UK. Biological Conservation 119: 1-18.

Wells, F.H. \& Lauenroth, W.K. 2007. The potential for horses to disperse alien plants along recreational trails. Rangeland Ecology \& Management 60: 574-577. 
744 Wessels, S., Eichberg, C., Storm, C. \& Schwabe, A. 2008. Do plant-community-based grazing regimes lead to

745 epizoochorous dispersal of high proportions of target species? Flora 203: 304-326.

746 Whinam, J., Chilcott, N. \& Bergstrom, D.M. 2005. Subantarctic hitchhikers: expeditioners as vectors for the 747 introduction of alien organisms. Biological Conservation 121: 207-219.

748 Whyte, I.D. 1999. Rural Europe since 1500: Areas of retardation and tradition. In: Butlin, R.A. \& Dodgshon, 749 R.A. (eds.) An historical geography of Europe, pp. 243-258. Oxford University Press, Oxford.

750 Wichmann, M.C., Alexander, M.J., Soons, M.B., Galsworthy, S., Dunne, L., Gould, R., Fairfax, C., Niggemann, 751 M., Hails, R.S. \& Bullock, J.M. 2009. Human-mediated dispersal of seeds over long distances. Proceedings of 752 the Royal Society B-Biological Sciences 276: 523-532.

753 Williams, E.D. 1984. Changes during 3 years in the size and composition of the seed bank beneath a long-term 754 pasture as influenced by defoliation and fertilizer regime. Journal of Applied Ecology 21: 603-615.

755 Woodruffe-Peacock, E.A. 1918. A Fox-Covert Study. Journal of Ecology 6: 110-125.

756 Zechmeister, H.G., Schmitzberger, I., Steurer, B., Peterseil, J. \& Wrbka, T. 2003. The influence of land-use 757 practices and economics on plant species richness in meadows. Biological Conservation 114: 165-177.

758 Zwaenepoel, A., Roovers, P. \& Hermy, M. 2006. Motor vehicles as vectors of plant species from road verges in 759 a suburban environment. Basic and Applied Ecology 7: 83-93. 
Table 1. Human-mediated seed transport in natural conditions in the European rural landscape. Methods vary widely between studies.

\begin{tabular}{|c|c|c|c|c|c|c|}
\hline & Reference & Country & Vector & $\begin{array}{l}\text { Number of } \\
\text { replicates }\end{array}$ & Total seeds ${ }^{1}$ & $\begin{array}{l}\text { Number of identified } \\
\text { species* }\end{array}$ \\
\hline \multirow[t]{6}{*}{ Epizoochory } & Couvreur et al. 2004a & Belgium & Cattle & 125 & 3692 & 63 \\
\hline & & & Donkey & 46 & 2483 & 33 \\
\hline & & & Horse & 30 & 210 & 20 \\
\hline & Couvreur et al. 2005a & Belgium & Donkey & 41 & NA & 29 \\
\hline & Fischer et al. 1996 & Germany & Sheep & 16 & 8511 & 85 \\
\hline & Wessels et al. 2008 & Germany & Sheep & $41-63$ & 9420 & 56 \\
\hline \multirow[t]{19}{*}{ Endozoochory } & Bakker and Olff 2003 & Netherlands & Cattle & 30 & 6124 & 35 \\
\hline & Bruun and Poschlod 2006 & Germany & Cattle & 48 & 14703 & 56 \\
\hline & Cosyns et al. 2005a & Belgium & Cattle and Horse & 51 & 59049 & 117 \\
\hline & Cosyns et al. 2006 & Belgium & Cattle & 12 & 18974 & 50 \\
\hline & & & Horse & 12 & 10808 & 49 \\
\hline & Cosyns and Hoffmann 2005 & France/Belgium & Horse & 56 & 53493 & 106 \\
\hline & Couvreur et al. $2005 \mathrm{a}$ & Belgium & Donkey & 14 & NA & 53 \\
\hline & Dai, 2000 & Sweden & Cattle & 30 & 393 & 26 \\
\hline & Eichberg et al. 2007 & Germany & Sheep & 32 & 2669 & 28 \\
\hline & Kuiters and Huiskes 2010 & Belgium/Netherlands & Sheep & 24 & 11130 & 72 \\
\hline & Malo and Suarez 1995 & Spain & Cattle (Spring) & 8 & 1373 & 46 \\
\hline & & Spain & Cattle (Winter) & 8 & 17 & 5 \\
\hline & Mitlacher et al. 2002 & Sweden & Cattle and Sheep & 29 & 1504 & 44 \\
\hline & Mouissie et al. 2005b & Netherlands & Cattle & 50 & $1161\left(\mathrm{~kg}^{-1}\right)$ & 51 \\
\hline & & Netherlands & Cattle & 10 & $4605\left(\mathrm{~kg}^{-1}\right)$ & 34 \\
\hline & & Netherlands & Cattle & 15 & $1095\left(\mathrm{~kg}^{-1}\right)$ & 39 \\
\hline & & Netherlands & Horse & 10 & $661\left(\mathrm{~kg}^{-1}\right)$ & 35 \\
\hline & & Netherlands & Sheep & 10 & $527\left(\mathrm{~kg}^{-1}\right)$ & 31 \\
\hline & Pakeman et al. 2002 & UK & Sheep & 12 & $359\left(\mathrm{~kg}^{-1}\right)$ & 21 \\
\hline \multirow[t]{10}{*}{ Motor Vehicles } & Hodkinson and Thompson 1997 & UK & Car & 201 & 367 & 37 \\
\hline & Mayer 2000 & Germany & Tractor $^{2}$ & 1 & 6 & 4 \\
\hline & & & Plough $^{2}$ & 1 & 1945 & 35 \\
\hline & & & Heavy cultivator $^{2}$ & 1 & 844 & 28 \\
\hline & & & Rotary tiller ${ }^{2}$ & 1 & 320 & 30 \\
\hline & & & Rotary harrow ${ }^{2}$ & 1 & 658 & 25 \\
\hline & & & Curry comb ${ }^{2}$ & 1 & 460 & 11 \\
\hline & Schmidt 1989 & Germany & Car & 4 & 3926 & 124 \\
\hline & Strykstra et al. 1997 & & Mowing machinery & 7 & & 27 \\
\hline & Zwaenepoel et al. 2006 & Belgium & Car & 240 & 690 & 33 \\
\hline \multirow[t]{2}{*}{ Humans } & Clifford 1956 & Ireland & Boots & Unknown (22.1g) & 65 & 11 \\
\hline & Wooderuffe-Peacock 1918 & UK & Clothes & 3 & & 19 \\
\hline
\end{tabular}

${ }^{1}$ As far as can be deduced from the text. This includes both replication and pseudoreplication, i.e. 75 could mean either 75 individuals, or one individual sampled 75 times. Epizoochorous units are animals, endozoochorous are "samples".

${ }^{2}$ In this study, machinery was driven through mud of varying soil dry matter, but species lists are not given. Displayed here are the individual runs that yielded the most seeds and species. 
